REGINA FUCHS-GODEC', MIOMIR G. PAVLOVIĆ $2 *$, MILORAD V. TOMIĆ 3

${ }^{1}$ University of Maribor, Faculty of Chemistry and Chemical Engineering, Maribor, Slovenia, ${ }^{2}$ University of Belgrade, IHTMCEH, Belgrade, Serbia, ${ }^{3}$ University of East Sarajevo, Faculty of Technology Zvornik, Zvornik, Republic of Srpska, Bosnia and Herzegovina
Scientific paper

ISSN 0351-9465, E-ISSN 2466-2585

UDC:620.181:669.183.57.2

doi:10.5937/ZasMat1601026F

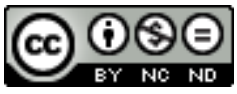

Zastita Materijala 57 (1)

$26-32(2016)$

\title{
The kinetics of passivation based on the reduction of current density under potentiostatic conditions for a martensitic stainless steel
}

\begin{abstract}
The potentiostatic method and the theory of "topochemical reactions" in the kinetics of the active dissolution and passivation process of AISI 420 stainless steel were studied. It was found that, to a great extent, the number of conversion steps is depended on the imposed potential. The experimentally obtained results were partially explained using Okamoto's theory of passivation.

Keywords: Topochemical reactions, AISI 420, kinetic of passivation, passivation processes.
\end{abstract}

\section{INTRODUCTION}

It is well known that electrochemical methods are extremely useful for the study of aqueous corrosion phenomena. The corrosion of metals is an electrochemical process, which requires that there are anodes and cathodes in electrical contact, and that there is an ionic conduction path through the electrolyte. The electrochemical process consists of electron flow between anodic and cathodic areas, quantifying the rates of the oxidation and reduction reactions that occur at the surfaces. The kinetics of the corrosion process can be assessed by monitoring this electron flow [1].

One method of monitoring is the potentiostatic method, where the working electrode is maintained at a constant potential, and current changes over time are measured. The rate at which the current alters can indicate the different kinetics of the corrosion reactions, which are either accelerated or hindered [korozija]. In the case of potentiostatic measurements, pure charge transfer overvoltage, or diffusion overvoltage, or a combination of both can be obtained. However, as long as current density decreases linearly with $\sqrt{t}$ (where $\mathrm{t}$-is time), the process is controlled by the charge transfer overvoltage. In most cases, when a diffusion overvoltage occur then current density

\footnotetext{
${ }^{*}$ Corresponding author: M. G. Pavlović

E-mail: duki@tmf.bg.ac.rs

Paper received: 19. 08. 2015.

Paper accepted: 10. 10. 2015.

Paper is available on the website: www.idk.org.rs/casopis
}

becomes proportional to $1 / \sqrt{t}$. If charge transfer and diffusion control occurs at the same time, the dependency of current density on time is like that already observed by other authors [2]. Making use of the available literature [2,3], it was possible to evaluate the initial current density, and thus the reaction rate, too.

\section{EXPERIMENTAL PART}

The test specimens, with a diameter of $16 \mathrm{~mm}$ and a thickness of $3 \mathrm{~mm}$, which were prepared from $13 \%$ Cr-martensitic stainless steels, AISI 420 or X20Cr13 (from the Ravne Steel Mill), were in the annealed condition. A lot of carbides were therefore included (see Figure 1).

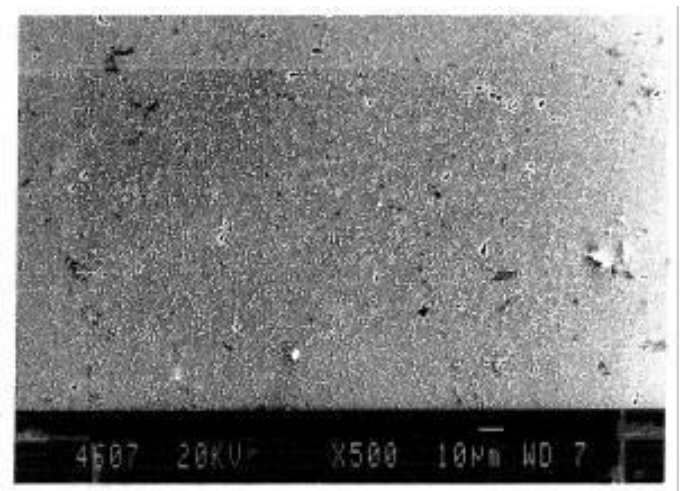

Figure 1 - SEM of microstructure of annealed AISI 420

The specimens were mechanically polished using Si-C grinding papers and finally diamond pastes to near mirror quality. For the subsequent microstructural studies a JOEL ISM-840/A Scanning Microscope was used. The test solutions 
used were mixtures of $0.1 \mathrm{M} \mathrm{H}_{2} \mathrm{SO}_{4}$ and $0.1 \mathrm{M}$ $\mathrm{Na}_{2} \mathrm{SO}_{4}$, with $\mathrm{pH}$-values of $2.42,2.85$ and 3.33.

These $\mathrm{pH}$-values were chosen taking into account the results of a previous investigation which indicated that AISI 420 steel corrodes more rapidly in the case of $\mathrm{pH}$-values lower than 2.85 . Above 2.85, the AISI 420 steel has been shown to be corrosion resistant (see Figure 2) [4].

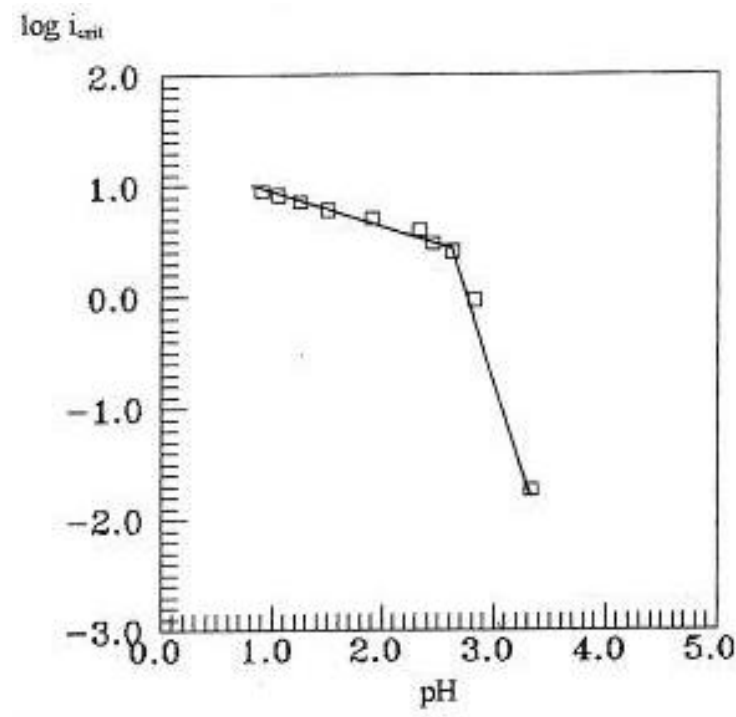

Figure 2 - Log $i_{\text {critt }}$ plotted against $\mathrm{pH}$ for AISI 420 steel ( $i_{\text {critt }}$ is the current density at the top of the anodic peak in the polarization curve)

For the corrosion investigations a Green cell, a WENKING Potentiogalvanoscan (used as a Potentiostat) and a compatible PC were used. The test specimens, with an exposed surface area of approximately $1 \mathrm{~cm}^{2}$, were fixed in a PTFE holder as working electrode. A saturated calomel electrode (SCE) was used as reference electrode, the counter electrode being made from $\mathrm{Pt}$.

Each experiment was carried out using a freshly polished electrode. The working electrode was kept at a potential of $-0.7 \mathrm{~V}$ versus SCE for 3 minutes, to reduce the oxide film, then for 1 minute at OCP (open circuit potential) to get a reproducible initial state. The potentiostatic measurements were made within the range from -0.7 to $0.3 \mathrm{~V}$ versus SCE. They were performed without deaeration at a temperature of $(30.0 \pm 0.1){ }^{\circ} \mathrm{C}$.

\section{RESULTS AND DISCUSSION}

\subsection{Topochemical reactions}

The purpose of the study was to investigate the change of the reaction rate of the chosen steel while passing through the active-passive state, and in part of the passive area.

Current densities were plotted against $1 / \sqrt{t}$, and three different types of dependencies were obtained, as shown in Figure3.

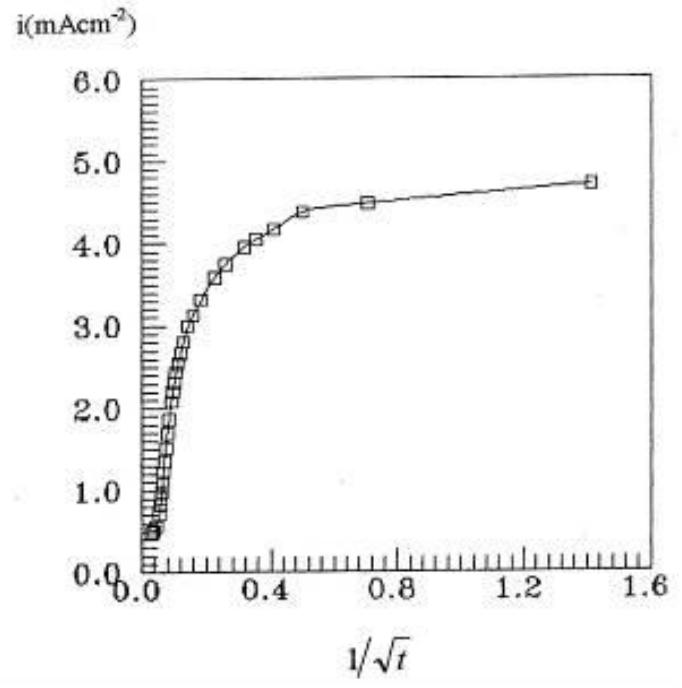

a)

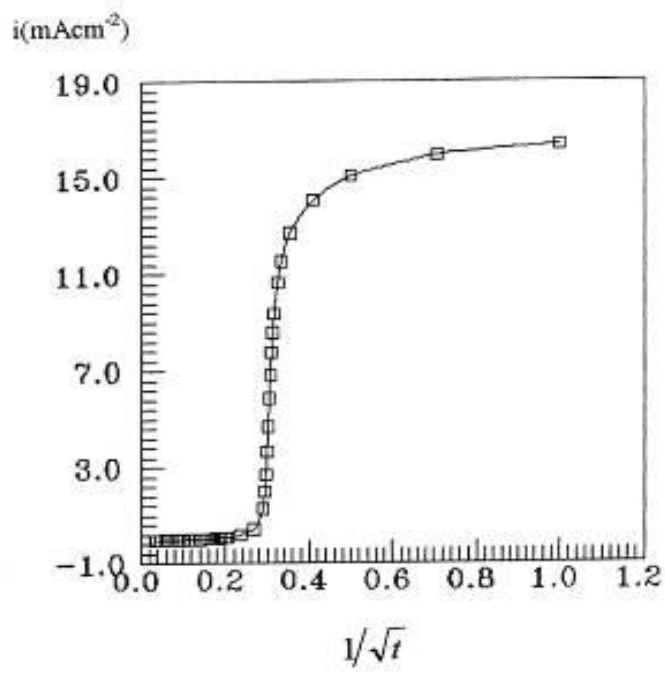

b)

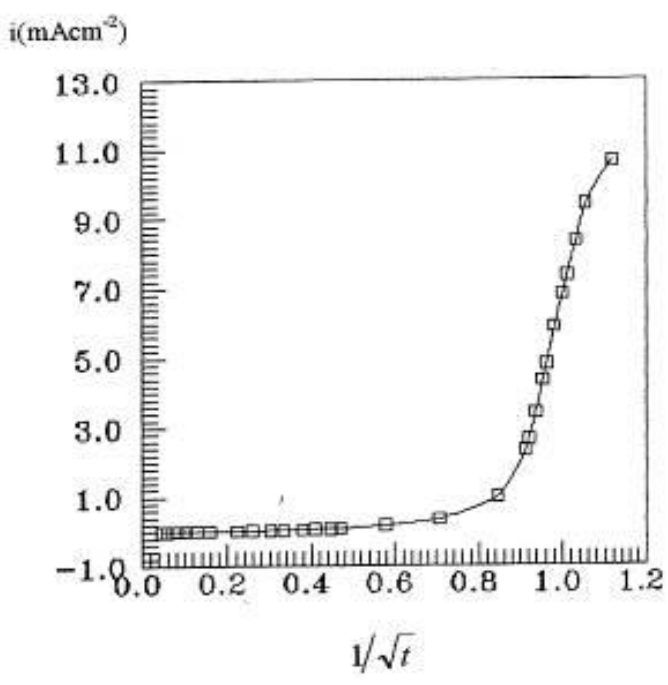

c)

Figure 3 - The experimentally obtained relation between current density and $1 / \sqrt{t}$ ( $t-$ time) for AISI 420 steel at $p H=2.85$ with a) $E=-0.45 \mathrm{~V}$ versus SCE b) $E=-0.1 V$ versus SCE and c) $E=$ $0.3 \mathrm{~V}$ versus $S C E$ 
Figure 4 shows the polarization curve of AISI 420 steel. In the region from the rest potential to the top of the anodic peak $(A)$, the upper part of an S-curve was obtained, passing to the passive state (B), a completely S-curve and in the passive region (C), the lower part of an S-curve was obtained (see Figure 3).

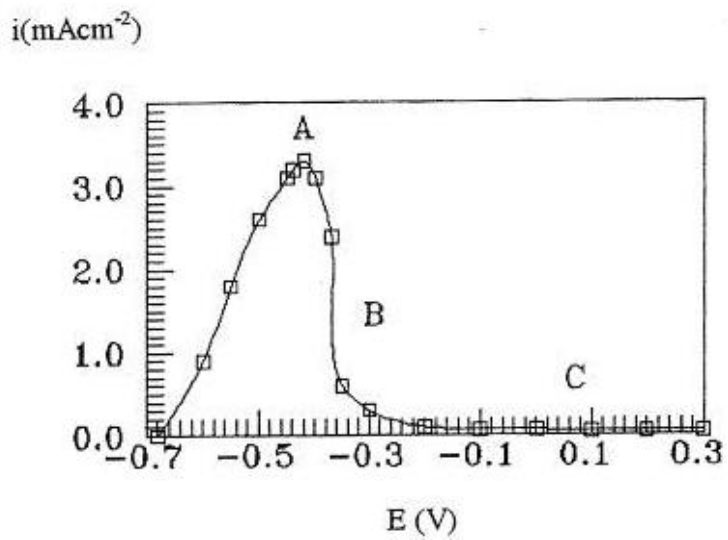

Figure 4 - The polarization curve of AISI 420 steel in a solution of $0.1 \mathrm{M} \mathrm{H}_{2} \mathrm{SO}_{4}+0.1 \mathrm{M} \mathrm{Na}_{2} \mathrm{SO}_{4}, \mathrm{pH}=$ 2.85

Such $\mathrm{S}$ or sigmoid curves are typical for "topochemical reactions" or for reactions, where the final product is formed via a number of intermediate steps. Under the heading of "topochemical reactions" should be included numerous processes, which include among the reactants and among the products too, at least one solid substance, e.g.:

$$
\begin{aligned}
& A \text { (solid) } \Rightarrow B \text { (solid) }+G \text { (gas) } \\
& A \text { (solid) }+B \text { (gas) } \Rightarrow C \text { (solid) }+D \text { (gas) }
\end{aligned}
$$

As a third alternative, in the previous equation a liquid could be involved instead of a gas. All such re-actions have one specific feature in common, i.e. the process proceeds at the interface between two solid phases. For topochemical reactions the reaction rate $\mathrm{v}$, is defined as the change over time of the degree of conversion, $\xi$. Thus the reaction rate is defined as

$$
v=\frac{d \xi}{d t},
$$

where

$$
\xi=\frac{N_{0}-N}{N_{0}}
$$

In equation (2) $\mathrm{N}_{0}$ denotes the initial amount of the reactant, and $\mathrm{N}$ the instantaneous amount. The typical sigmoid curve for that kind of reactions was shown in Figure 5 and the dependence of the extent of reaction on time and the dependence of the reaction rate just as well.

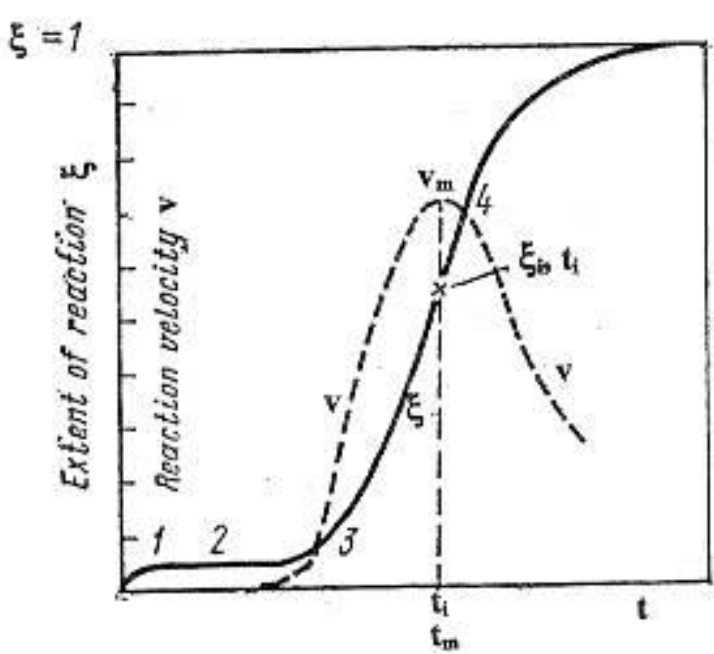

Figure 5 - The generalized curve for a typical topochemical reaction. The solid curve represents decomposition over time, whereas the dashed curve indicates the dependence of the reaction rate on time [5]

According to the literature [5,6], (see Figure 5) the first section of the sigmoid curve corresponds to the rapid initial evolution of gas, which is most frequently caused by the desorption of gas adsorbed physically onto the surface of the solid. The second section corresponds to the induction period, during which the reaction either does not occur at all or else proceeds very slowly. This induction period is followed by the acceleratory section three, which ends at the point of inflection of the curve $\left(\xi_{i}, t_{i}\right)$. It is clear that the reaction rate reaches a maximum at the point of inflection. Section four corresponds to the retardation of the reaction, as it nears completion. The period of initial gas evolution (the first section) is often found to be missing. Not infrequently cases have been observed where sections 1,2 and 3 are missing, and the reaction proceeds from the start on with the greatest speed. It is possible that in some cases the initial periods 1,2 and 3 are very short, so that they become unobservable.

With more sensitive instruments or some new methods it would be possible to achieve more in this "field of work".

Although many theories exist (e.g. those of Mc Donald and Hinshelwood, Fraenkel and Getz, and Garner), nevertheless, at the present time, there is no generally adopted theory of topochemical reactions, and there are no topochemical equations which could adequately describe all the steps to the end-product. According to Fraenkel and Getz [5], conversion starts at separate nucleipoints or reference points that are formed on the crystal surface, this being evidently associated with the various types of imperfections in the crystal lattice. 
In the simplest case, these may be, for example, misfit dislocations climbing to the surface, vacancies, accumulations of atoms (ions) in the interstices, or dispersed particles-carbides. These structural units or elements of the crystal lattice are characterized by an increased free energy, and hence they exhibit higher reactivity. The nuclei are also called potential nucleating centers. More about the mechanism of topochemical reactions can be found in the literature [5-7].

The sigmoid curve of a topochemical reaction can be described by the Erofeev equation [5].

$$
\xi=1-e^{-k t^{n}},
$$

where $k$ is the rate constant, $n=\sigma+a$, $\sigma$ being the number of elementary steps in the reaction, a being the number of directions in which the nuclei grow (a $=1,2$, or 3 ), and $n$ can be defined using the following expression, taking into account the data at the inflection point $(\mathrm{m})$.

$$
n=1+\frac{\left(\frac{\Delta \zeta}{\Delta t}\right)_{m} \square t_{m}}{1-\zeta_{m}}
$$

\subsection{Experimental results}

The theory mentioned above has been used for the interpretation of the experimentally obtained results. The modified equations (2) and (4) have been used, substituting the initial and instantaneous currents, instead of the amount of the reactants, into equation (2), based on the supposition that the concentrations of the reactants are proportional to the current densities. Since plots of current densities versus $1 / \sqrt{t}$ provide sigmoid curves, $1 / \sqrt{t}$ was substituted for $t$ in equation (4) (these are predominantly diffusion controlled reactions). The modified equation (4) is then

$$
n^{\prime}=\sqrt{1+\frac{\left(\frac{\Delta \xi}{\Delta 1 / \sqrt{t}}\right)_{m} \cdot\left(1 / \sqrt{t)_{m}}\right.}{1-\xi_{m}}}
$$

where $n^{\prime}$ is the number of conversions during the reaction.

The passivation process was our main target of interest, so only measurements from the top of the anodic peak to the region of total passivation were considered. In the solutions with $\mathrm{pH}$-values of 2.42 and 2.85, two conversions were observed at the top of the anodic peak, three were observed in the region of passive film formation, and five were observed in the passive part (see Table 1). Taking into account the chosen material of the working electrode, the following mechanisms could be supposed.
The first step would include the desorption of adsorbed hydrogen. Two basic mechanisms have been accepted for hydrogen evolution. These are the recombination mechanisms [8-10]:

$$
\begin{aligned}
& M+H^{+}+e^{-} \Rightarrow M H_{a d s} \\
& M H_{a d s}+H^{+} \Rightarrow H_{2}+2 M
\end{aligned}
$$

and the electrochemical desorption mechanism [810]:

$$
\begin{aligned}
& M+H^{+}+e^{-} \Rightarrow M H_{a d s} \\
& M H_{a d s}+H^{+}+e^{-} \Rightarrow H_{2}+M
\end{aligned}
$$

The second step would indicate the formation of solid ferrous sulphate, from the previously dissolved metal [11]:

$$
\mathrm{Fe}^{2+}+\mathrm{H}_{2} \mathrm{SO}_{4} \Leftrightarrow \mathrm{FeSO}_{4}+2 \mathrm{H}^{+}
$$

The third step would be attributed to the beginning of the passivation process.

In his model, Okamoto has described passivation as a dynamic process [12]. He suggested that the bound water is incorporated mainly in accordance with the Cr-enrichment in the passive film, but that it is also variable in character, depending on the passivation potential, time and temperature. At less positive potentials, the passive film at first contains a large amount of bound water. The transfer from the first kind to the second kind of bound water, at a higher potential, is associated with the first deprotonation of aqua to a hydrated oxide film, and with the further deprotonation the film changes completely into a perfect oxide [1315].

In accordance with Okamoto's dynamic model, at potentials exceeding the Flade potential, three steps, or conversions, were observed. It may be supposed that the solid ferrous sulphate starts to dissolve and that a passive film forms. When the potential became more positive than $-0.2 \mathrm{~V}$ (SCE), the number of steps increased to five (see Table.1), because of the two assumed deprotonations.

$\mathrm{H}_{2} \mathrm{O}-\mathrm{M}-\mathrm{H}_{2} \mathrm{O} \Leftrightarrow^{-2 \mathrm{H}^{+}} \mathrm{OH}-\mathrm{M}-\mathrm{OH} \Leftrightarrow^{-2 \mathrm{H}^{+}} \mathrm{O}-\mathrm{M}-\mathrm{O}$

In the solution with a pH-value of 2.85 , at a potential of $0.2 \mathrm{~V}(\mathrm{SCE})$, the number of steps decreases from five to four; this can be ascribed to the greatly accelerated reaction of hydrogen desorption at a more positive potential. Unfortunately, the response of the used instrument was too low, which may have caused the loss of the first step. Some confirmation of the greatly accelerated first step reaction is given by the degree of conversion where $\xi$ at which the reaction rate at the inflection point reaches a maximum value. 
Table 1 - The number of conversion steps, evaluated according to equation (5). * inflection points determined using the "Metropolis" method, these points being inserted into equation (5) in order to evaluate the number of conversion step.

\begin{tabular}{|c|c|c|c|c|c|c|c|c|c|}
\hline \multirow{2}{*}{$E(V)$} & \multicolumn{3}{|c|}{$\mathrm{pH}=2.42$} & \multicolumn{3}{|c|}{$\mathrm{pH}=2.85$} & \multicolumn{3}{|c|}{$\mathrm{pH}=3.31$} \\
\hline & $\mathrm{n}$ & $\sigma$ & $\mathrm{a}$ & $\mathrm{n}$ & $\sigma$ & a & $\mathrm{n}$ & $\sigma$ & $\mathrm{a}$ \\
\hline \multirow{2}{*}{-0.47} & & - & & & - & & 1.488 & & \\
\hline & & & & & & & $1.195^{\star}$ & 2 & - \\
\hline \multirow{2}{*}{-0.45} & & - & & & - & & 1.686 & & \\
\hline & & & & & & & $1.464^{*}$ & 2 & - \\
\hline \multirow{2}{*}{-0.42} & & - & & 1.812 & & & & - & \\
\hline & & & & $1.255^{\star}$ & 2 & - & & & \\
\hline \multirow{2}{*}{-0.40} & 1.613 & & & 1.860 & & & 1.865 & & \\
\hline & $1.065^{\star}$ & 2 & - & $1.616^{*}$ & 2 & - & $1.384^{*}$ & 2 & - \\
\hline \multirow{2}{*}{-0.37} & 2.150 & & & & - & & & - & \\
\hline & $2.025^{\star}$ & 2 & - & & & & & & \\
\hline \multirow{2}{*}{-0.35} & 2.090 & & & 2.840 & & & 2.042 & & \\
\hline & $2.025^{\star}$ & 2 & - & $2.377^{*}$ & 3 & - & $1.312^{*}$ & 2 & - \\
\hline \multirow{2}{*}{-0.30} & 2.553 & & & 2.746 & & & 2.316 & & \\
\hline & $2.817^{*}$ & 3 & - & $2.999^{*}$ & 3 & - & $1.756^{*}$ & 2 & - \\
\hline \multirow{2}{*}{-0.20} & 4.139 & & & 4.630 & & & 5.386 & & \\
\hline & $4.062^{*}$ & 4 & - & $5.740^{*}$ & 5 & $0-1$ & $5.820^{*}$ & 4 & $1-2$ \\
\hline \multirow{2}{*}{-0.10} & 5.314 & & & 6.500 & & & 5.073 & & \\
\hline & $5.825^{*}$ & 5 & $1-2$ & $6.288^{*}$ & 5 & $1-2$ & $5.623^{*}$ & 4 & $1-2$ \\
\hline \multirow{2}{*}{0.00} & 7.329 & & & 6.143 & & & 5.591 & & \\
\hline & $6.560^{*}$ & 5 & $1-2$ & $6.615^{*}$ & 5 & $1-2$ & $5.387^{*}$ & 4 & $1-2$ \\
\hline \multirow{2}{*}{0.10} & 6.700 & & & 6.007 & & & 4.850 & & \\
\hline & $6.504^{*}$ & 5 & $1-2$ & $6.764^{*}$ & 5 & $1-2$ & $5.375^{\star}$ & 4 & $1-2$ \\
\hline \multirow{2}{*}{0.20} & 6.644 & & & 7.410 & & & 5.660 & & \\
\hline & $6.333^{*}$ & 5 & $1-2$ & $7.410^{*}$ & 5 & $1-2$ & $6.164^{*}$ & 4 & $1-2$ \\
\hline \multirow{2}{*}{0.30} & 6.300 & & & 6.973 & & & 5.686 & & \\
\hline & $5.830^{*}$ & 5 & $1-2$ & $6.551^{*}$ & 5 & $1-2$ & $6.657^{*}$ & 4 & $1-2$ \\
\hline
\end{tabular}

A certain change occurs at a $\mathrm{pH}$ of 3.31 , where the AISI 420 steel used in the tests shows resistance to acidic corrosion. Here, from a potential of $-0.2 \mathrm{~V}$ (SCE) towards more positive values only three steps are found instead of five, and the maximum reaction rate is achieved at $\xi=$ 0.33. It is possible that the first two steps are missing because they are more accelerated, or shorter than before on account of lower medium corrosivity (a higher $\mathrm{pH})$. At the maximum reaction rate $\xi<0.6$, so the upper part of the $S$-curve is unobservable (see Figure 3c).

According to equation (5), the number of conversion steps could be proved using a different approach. Taking into account the variation of concentration with time in a deposition process under diffusion control [16], the interfacial concentration of depositing ions is given by $\mathrm{C}_{\mathrm{x}=0}=$ $\mathrm{C}^{0}-\frac{2 i t^{1 / 2}}{n F \Pi^{1 / 2} D^{1 / 2}}$. Assuming the observed current density to be proportional to the ion concentration, $\mathrm{C}_{\mathrm{x}=0} \propto \mathrm{i}$ and $\mathrm{C}^{0} \propto \mathrm{i}_{\text {init }} \quad\left(\mathrm{i}_{\text {init }}\right.$ is the initial current density), and defining the degree of conversion by the expression $\xi=\frac{i_{\text {init }}-i}{i_{\text {init }}}$, one obtains $\frac{\xi}{1-\xi}$ $=\frac{2}{B n F \Pi^{1 / 2} D^{1 / 2}} \cdot \sqrt{t}$, (where $\mathrm{B}$ is a constant), or $\log \frac{1-\xi}{\xi}=\log \mathrm{B}^{\prime}+\log (1 / \sqrt{t})$, where $\mathrm{B}^{\prime}=$ $\frac{B n F \Pi^{1 / 2} D^{1 / 2}}{2}$ and could be assumed to be constant for any particular reaction step. Plots of $\log \left(\frac{1-\xi}{\xi}\right)$ against $\log \left(\frac{1}{\sqrt{t}}\right)$ have shown that the curve changes its slope as many times as the evaluated numbers of conversion (see Figure 6). 

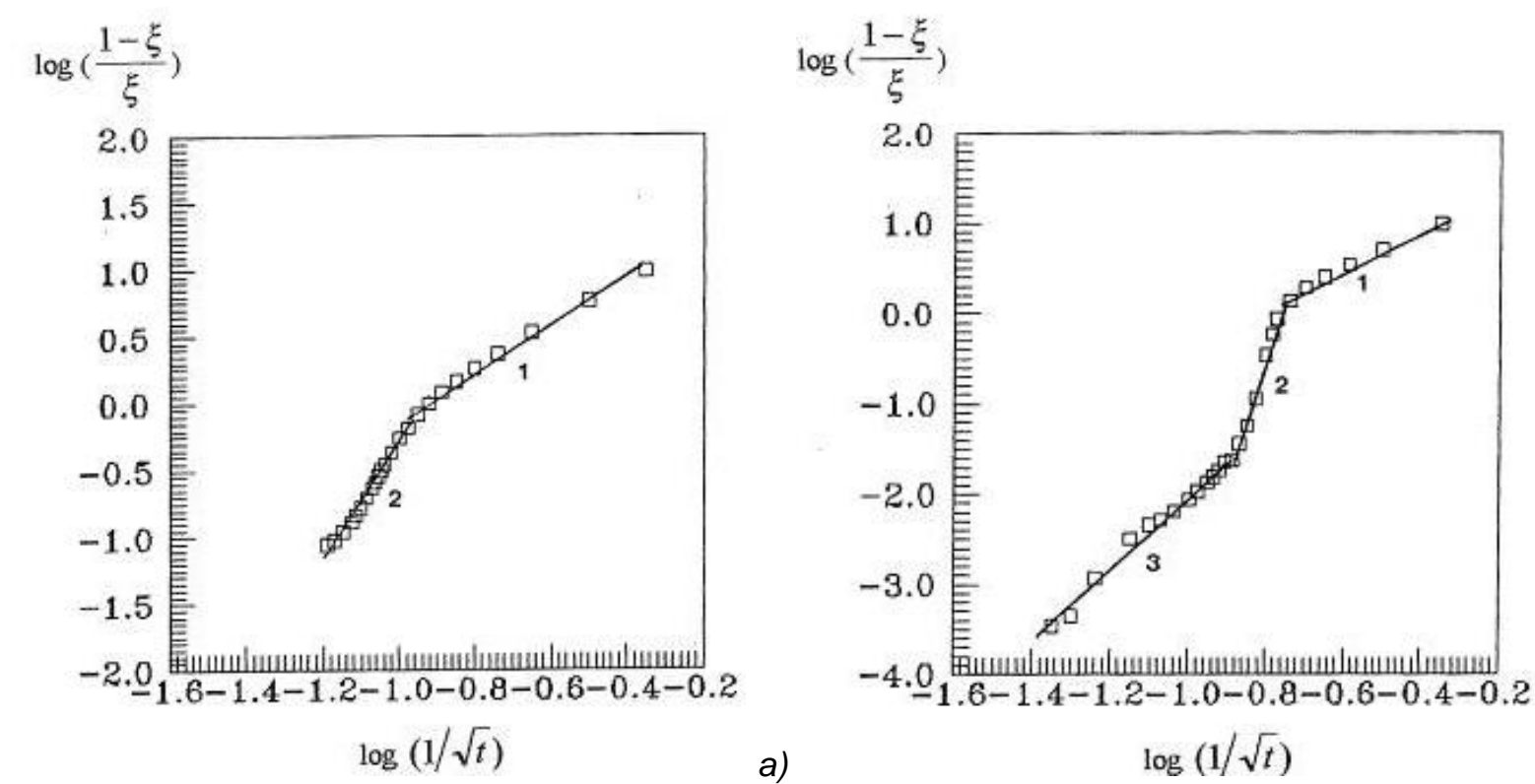

b)

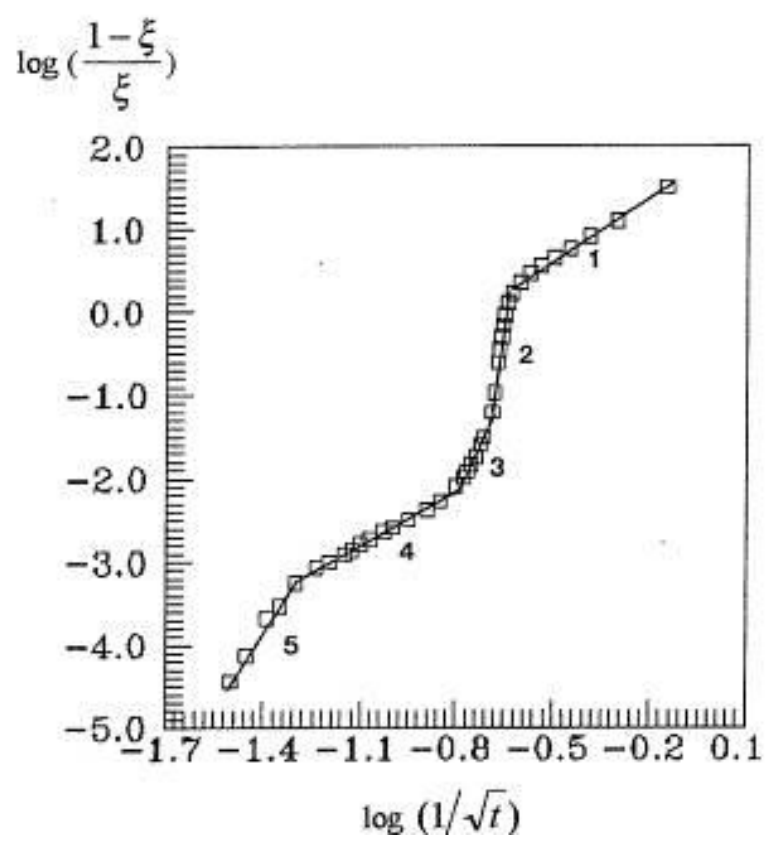

Figure 6 - The experimentally obtained relation between $\log \left(\frac{1-\xi}{\xi}\right)(\xi$-degree of conversion) and $\log (1 / \sqrt{t})$ for $A / S I 420$ steel at $p H=2.85$ and a) $E=-0.42 V$ versus SCE, b) $E=-0.3 V$ versus SCE and c) $E=-0.2 \vee$ versus SCE

\section{CONCLUSIONS}

1. The investigation has shown that the potentiostatic method can be very useful in research into the kinetics of the active dissolution and passivation processes of stainless steels.

2. The number of observed reactions depends, to a large extent, on the applied potential. At the top of the active peak two reactions can usually be detected, whereas at transition into the passive region three can be detected, and in the passive region five. This can be partly explained by taking into account the Okamoto, dynamic model of passivation [12]. A similar conclusion regarding progressive passive film formation has been made using the electrochemical noise method [17]. 


\section{Acknowledgements}

This work was financially supported by Slovenian Research Agency - ARRS, Ljubljana (www.arrs.gov.si) under research project "PhysicoChemical Processes on the Surface Layers and Application of Nanoparticles" (P2-0006) and by the Ministry of Education, Science and Technological Development of the Republic of Serbia under the research project No. 172046.

\section{REFERENCES}

[1] S.K.Sharma (2012) Green Corrosion Chemistry and Engineering: Opportunities and Challenges, John Wiley \& Sons, Weinheim, Germany

[2] K.J.Vetter (1961) Electrochemical Kinetics, SpringerVerlag Berlin Heidelberg, Germany

[3] H.Kaesche (2003) Corrosion of Metals, SpringerVerlag Berlin Heidelberg, Germany

[4] V.Doleček, R.Fuchs (1991) Electrochemical behaviour of $\mathrm{Cr}-13$ stainless steels in sulphate solutions, Vest. Slov. Kem. Druš., 38, 17-29

[5] E.N.Yeremin (1979) The Foundations of Chemical Kinetics, Mir Publishers, Moscow, Russia

[6] Z.Ahmad (2006) Principles of Corrosion Engineering and Corrosion Control, Elsevier, Oxford, United Kingdom

[7] A.Fattah-Alhosseini, (2013) Electrochemical Characterization of a Martensitic Stainless Steel, International Journal of ISSI, 10(2), 1-6

[8] L.L.Shreier (1977) Corrosion, vol.1 and 2, Newness Butterworths, London, United Kingdom

[9] R.Fuchs-Godec, A. Petek, V. Dolček (2002) Nucleation and Growth of a Passive Film on AISI
420 Martenistic Stainless Steel Under Potentiostatic Conditions, Acta Chim. Slov., 49, 139-148

[10] C.A.Gervasi, C.M.Méndez, A.E.Bolzán, P.D.Bilmes, C.L.Llorente (2015) Chemical composition and electronic structure of anodic passive films on low-C $13 \mathrm{CrNiMo}$ stainless steel, J. Solid State Electrochem, DOI 10.1007/s100008-015-2986-5

[11] G.-L.Song,C.-N.Cao,H.-C.Lin (1994) A kinetic model for the potential oscillation phenomenon of mild steel in conc. $\mathrm{H}_{2} \mathrm{SO}_{4}$, Corros. Sci., 36, 1491-1497

[12] H.Saito, T.Shibata, G.Okamoto (1979) The inhibitive action of bound water in the passive film of stainless steel against chloride corrosion Corros.Sci., 19, 693708

[13] K.Tachibana, K.Miya, K.Furuya, G.Okamoto (1990) Changes in the power spectral density of noise current on type 304 stainless steels during the long time passivation in sulfuric acid solutions, Corros.Sci., 3 527-532

[14] G.Okamoto (1973) Passive film of 18-8 stainless steel structure and its function, Corros.Sci., 13 (1973) 471-489.

[15] A.Fattah-alhosseini, M.M.Khalvan (2013) Semiconducting Properties of Passive Films Formed on AISI 420 Stainless Steel in Nitric Acid Solutions, Journal of Advanced Materials and Processing, 1(4), 15-22

[16] J.O'M.Bockris, A.K.N.Reddy (1977) Modern Electrochemistry, vol.1 and 2, Plenum Press, NewYork, p.1321

[17] M.Slemnik, A.Petek, V.Doleček (1995) Measurements of electrochemical noise on the passive layer of differently heat treated stainless steels, Werkstoffe und Korrosion, 46, 13-17.

\section{IZVOD}

\section{KINETIKA PASIVIZACIJE BAZIRANE NA REDUKCIJI GUSTINE STRUJE PRI POTENCIOSTATSKIM USLOVIMA ZA MARTENZITNI NERĐAJUĆI ČELIK}

Ispitivana je potenciostatska metoda i teorija "topohemijskih reakcija" u kinetici aktivnih procesa rastvaranja i pasivacije AISI 420 nerđajućeg čelika. Pokazano je da, u velikoj meri, broj stepena konverzije zavisi od primenjenog potencijala. Eksperimentalno dobijeni rezultati su delimično objašnjeni Okamotovom teorijom pasivacije.

Kljućne reči: Topohemijska reakcija, AISI 420, kinetika pasivacije, proces pasivacije.

Naučni rad

Rad primljen: 19. 08. 2015.

Rad prihvaćen: 10. 10. 2015.

Rad je dostupan na sajtu: www.idk.org.rs/casopis 